\title{
Corrigendum: Minimum information about a single amplified genome (MISAG) and a metagenome-assembled genome (MIMAG) of bacteria and archaea
}

Robert M Bowers, Nikos C Kyrpides, Ramunas Stepanauskas, Miranda Harmon-Smith, Devin Doud, T B K Reddy, Frederik Schulz, Jessica Jarett, Adam R Rivers, Emiley A Eloe-Fadrosh, Susannah G Tringe, Natalia N Ivanova, Alex Copeland, Alicia Clum, Eric D Becraft, Rex R Malmstrom, Bruce Birren, Mircea Podar, Peer Bork, George M Weinstock, George M Garrity, Jeremy A Dodsworth, Shibu Yooseph, Granger Sutton, Frank O Glöckner, Jack A Gilbert, William C Nelson, Steven J Hallam, Sean P Jungbluth, Thijs J G Ettema, Scott Tighe, Konstantinos T Konstantinidis, Wen-Tso Liu, Brett J Baker, Thomas Rattei, Jonathan A Eisen, Brian Hedlund, Katherine D McMahon, Noah Fierer, Rob Knight, Rob Finn, Guy Cochrane, Ilene Karsch-Mizrachi, Gene W Tyson, Christian Rinke, The Genome Standards Consortium, Alla Lapidus, Folker Meyer, Pelin Yilmaz, Donovan H Parks, A M Eren, Lynn Schriml, Jillian F Banfield, Philip Hugenholtz \& Tanja Woyke

Nat. Biotechnol. 35, 725-731 (2017); published online 8 August 2017; corrected after print 29 November 2017; corrected after print 7 December 2017

In the version of this article initially published, the author A. Murat Eren was listed as A.M. Eren. The corresponding affiliation was given as the Knapp Center for Biomedical Discovery, rather than Department of Medicine, University of Chicago, Chicago, Illinois, USA, and Marine Biological Laboratory, Woods Hole, Massachusetts, USA. The errors have been corrected in the HTML and PDF versions of the article as of 29 November 2017.

In the version of this article initially published, the following acknowledgment was omitted: A.L. was supported by the Russian Science Foundation (grant number 14-50-00069). The error has been corrected in the HTML and PDF versions of the article as of 7 December 2017.

\section{Corrigendum: Assisted reproductive technologies to prevent human mitochondrial disease transmission}

Andy Greenfield, Peter Braude, Frances Flinter, Robin Lovell-Badge, Caroline Ogilvie \& Anthony C F Perry Nat. Biotechnol. 35, 1059-1068 (2017); published online 9 November 2017; corrected after print 14 December 2017

In the version of this article initially published, in Table 2, first column, "m.13095T > C" should have been "m.130 $\mathrm{b}$ T $>$ C," where "b" refers to the footnote "Characters hidden to respect confidentiality," as with the other three from the Newcastle Group. In addition, the footnote "a”" for Table 2 should have read "http://hfeaarchive.uksouth.cloudapp.azure.com/www.hfea.gov.uk/docs/Fourth_scientific_review_mitochondria_2016.pdf” rather than "Personal communication." The following acknowledgment was omitted: "The authors thank Rob Taylor, Charlotte Alston, Emma Watson, Sam Byerley, Jane Stewart and Robert McFarland (Wellcome Centre for Mitochondrial Research Newcastle University and Newcastle upon Tyne Hospitals NHS Foundation Trust) for unpublished data included in Table 2." The errors have been corrected in the HTML and PDF versions of the article.

\section{Erratum: Random access in large-scale DNA data storage}

Lee Organick, Siena Dumas Ang, Yuan-Jyue Chen, Randolph Lopez, Sergey Yekhanin, Konstantin Makarychev, Miklos Z Racz, Govinda Kamath, Parikshit Gopalan, Bichlien Nguyen, Christopher N Takahashi, Sharon Newman, Hsing-Yeh Parker, Cyrus Rashtchian, Kendall Stewart, Gagan Gupta, Robert Carlson, John Mulligan, Douglas Carmean, Georg Seelig, Luis Ceze \& Karin Strauss Nat. Biotechnol. 36, 242-248 (2018); published online 19 February 2018; corrected after print 8 March 2018

In the version of this article initially published, the references in the reference list were in the wrong order; the references have been renumbered as follows: 3 as 2; 5 as 3; 6 as 8; 7 as 9; 8 as $11 ; 9$ as $6 ; 10$ as 12;11 as 5; 12 as 13; 13 as 7; 16 as 10; and no. 2, "Hoch, J.A. \& Losick, R. Panspermia, spores and the Bacillus subtilis genome. Nature 390, 237-238 (1997)," has been deleted. In addition, on p.242, end of paragraph 2, the citation in "experiments" " has been deleted. The errors have been corrected in the HTML and PDF versions of the article.

\section{Erratum: California voters and CIRM—will lightning strike twice?}

Laura DeFrancesco

Nat. Biotechnol. 36, 126-127 (2018); published online 6 February 2018; corrected after print 22 February 2018

In the version of this article initially published, the statement that CIRM's Transition Committee "considered requesting $\$ 5$ billion (or a total of $\$ 10$ billion) from the electorate" should have read the "Committee heard a presentation for another $\$ 5$-billion ( $\$ 10$-billion with interest) citizensponsored proposition." The error has been corrected in the HTML and PDF versions of the article. 